ELK

Asia Pacific Journals

www.elkjournals.com

\title{
ANALYSIS OF NON-PERFORMING LOAN INFLUENCING FACTORS OF BUSINESS GROUP COMMERCIAL BANK II LISTED ON INDONESIA STOCK EXCHANGE
}

\author{
Ade Dodiputera Poerba \\ Master of Management Study Program, \\ Postgraduate Program \\ Universitas Mercu Buana Jakarta \\ dodi.prbft@gmail.com
}

Augustina Kurniasih
Master of Management Study Program,
Postgraduate Program
Universitas Mercu Buana Jakarta
augustina.kurniasih@mercubuana.ac.id

ABSTRACT

The banking sector has an important role in the growth of country's economy. Disbursed loans to the debtors are assets that need to be properly managed so that Non Performing Loans will not increase. Therefore, Non Performing Loan becomes an important reference to measure the performance of a bank. This study aims to determine and analyze the influence of independent variables, namely Capital Adequacy Ratio (CAR), Net Interest Margin (NIM), Operating Expense to Operating Income (BOPO), Return on Assets (ROA), Loan Growth, and Interest Rate (BI Rate) to the dependent variable, namely Non Performing Loan (NPL). The sample of the research was conducted on 15 banks of BUKU II (Business Group Commercial Bank II with core capital of one trillion rupiahs to less than five trillion rupiahs) that met the criteria of the sample based on the purposive sampling. The study was conducted from the period of 2013-2017. The used method analysis is panel data regression method which the best model test result is Random Effect. The result of the research shows that the variable of ROA and Loan Growth have negative and significant influence to NPL, BOPO variable has negative but not significant influence to NPL, while NIM, CAR, Inflation, and Interest Rate (BI Rate) variable have positive but not significant influence to NPL.

Keywords: BUKU II banks, Non-Performing Loan, Capital Adequacy Ratio, Net Interest Margin, Operating Expense to Operating Income, Return on Assets, Loan Growth, Inflation, Interest Rate (BI Rate), Random Effect

\section{INTRODUCTION}

The bank is a financial institution licensed that acts as a financial intermediary between parties who have funds with parties who need funds. Banks implement trust and prudence functions to ensure people in using banking services. The
Bank has main activity in financial management that has a systematic inherent risk. The risk of losses that occur in a bank can have an impact not only on the bank, but also affect the customer and the economy as a whole. Banks must implement proper and appropriate 
risk management to prevent a sustainable bank loss, where if this happens, the bank can enter the bankruptcy stage which has the potential to trigger a systemic impact inherent in the banking industry.

In (Ref Figure 1), the Non Performing Loan (NPL), which is the ratio of loans upon which the debtor has not made the scheduled payments for a period, tends to increase from year to year, followed by increment in the number of loans and bank deposits. Increased NPL indicates a decrease in loan demand as a negative impact of the economic crisis in 2013 which not only reduced loan demand, but also forced debtor companies into an increasingly tight competition climate so that these conditions made it difficult for debtors to pay their obligations according to deadline loan time. Banks are often faced with nonperforming loans that encourage banks to make various policies, one of which is by raising interest rates. However, every banking policy has a negative impact, for example by increasing lending rates will increase debtor interest costs and ultimately disrupt cash flow so that loan repayment becomes problematic. The next impact will affect the level of profit that will be obtained by the bank later.

In January 2017, OJK (Otoritas Jasa Keuangan), as Indonesian banking supervisory institution, recorded that there were 22 banks with non-performing loans ratio (NPL Gross) of more than $5 \%$, where as many as 5 banks came from the BUKU (Bank Umum Kelompok Usaha) 1 category or those with core capital of less than 1 trillion rupiahs, 11 banks came from the BUKU 2 category or those with core capital of 1 trillion rupiahs to less than 5 trillion rupiahs. The remaining 6 banks came from the BUKU 3 category or those with core capital of 5 trillion rupiahs to less than 30 trillion rupiahs. The number of banks with gross NPLs above $5 \%$ increased when compared to 2016 which only amounted to 19 banks. Based on the bank's BUKU, on average from 2014 to 2017, the highest NPL was found in BUKU II, which was $2.85 \%$ and the lowest NPL was at BUKU I, which was $2.07 \%$.

There have been many studies conducted by previous researchers to analyze what factors influencing NPL in which there are researches gap. Therefore, this study focuses on BUKU II banks listed on the IDX (Indonesia Stock Exchange) by using variables that affect the NPL, namely Capital Adequacy Ratio (CAR), Net Interest Margin (NIM), Operating Expense to Operating Income (BOPO), Return on Assets (ROA), Loan Growth, Inflation, and Interest Rate (BI Rate). 


\section{LITERATURE REVIEW}

One of the banking business activities is providing loan. According to Kasmir (2013), the provided loan has several elements, namely the element of trust between the creditor and debtor, the element of the time period, the element of transfer of economic value, the element of risk in distributing loan, and the element of written approval / contract as proof of the agreement between the creditor and debtor. In each lending process, the bank will conduct a process of loan evaluation quantitatively and qualitatively. After that, the loan negotiation process is carried out, such as negotiating the loan period, large loan ceiling, amount of loan payments, terms and conditions that must be fulfilled, collateral, and others.

In general, loan analysis is carried out using the 5C's principle, namely Character (the nature of the person to be given loan must be trustworthy), Capacity (assessment of the ability to pay obligations), Capital (own capital), collateral (collateral that can be used as secondary payment if it fails to pay), and Condition (social, political, economic and other conditions that may affect the debtor's business activities).

Indonesian Banking is inseparable from risks that can cause a financial loss. Therefore, the bank supervision institution conducts bank supervision and inspection based on several risks, one of which is credit risk, namely the risk arising as a result of counterparty failure in fulfilling its obligations. According to Tohir (2013), loan monitoring must be well and actively conducted. If monitoring of the loan is carried out properly, then the problematic loans that will occur can be identified as early as possible. Non-performing loans usually have special signs, such as improper or declining business growth, one man show management system (most will become problematic if the person goes, is sick, or dies), weakness or fraud that occurs in the marketing or finance department debtors, mistakes in choosing technology, leverage ratio is too high, bad attitude from debtors (eg manipulating financial statements), and others.

In distributing loan given to debtors has several risks, one of which is the risk of non-payment of loan that has been given to the debtor or credit risk. Non-Performing Loans (NPLs) are one part of bank credit risk. According to Kasmir (2013), NPL is a loan in which there are obstacles due to two elements, namely from the banking sector in analyzing and from the customers who intentionally or unintentionally do not pay their obligations. Non-performing loans represent a situation in which the approval of the loan repayment is at risk of default by the debtor. 
According to Bank of Indonesia regulation No 14/15/PBI/2012 about Asset Quality Assessment for Commercial Banks, NPL can be classified into 3 sections, namely substandard loan or called collectability 3 (delinquent 91 days to 120 days), doubtful loan or called collectability 4 (delinquent 121 days to 180 days), and loss loan or also called collectability 5 (delinquent more than 180 days). An increase in NPLs in large numbers can cause problems for the health of banks, so banks are always required to apply the precautionary principle in providing loan so that the NPLs can be maintained and managed properly. The Financial Services Authority (namely OJK in Indonesia) is currently still applying a reasonable level of NPL of a maximum of $5 \%$ of the total loan provided by each bank to its debtor.

Capital Adequacy Ratio (CAR) is the ratio of a bank's capital in relation to its risk weighted assets and current liabilities This ratio is generally used to measure the adequacy of a bank to support assets that have risks, such as loans. According to Ali (2004), to reduce the risk of loan problems, the bank provides funds for business development purposes and accommodates the risk of loss of funds caused by bank operations called the Capital Adequacy Ratio (CAR).
Net Interest Margin (NIM) is a ratio used as a measure of a bank's ability to manage its productive assets to generate net interest income. The amount of interest income is determined from the interest rate component provided by the bank to bank customers. Banks need to be careful in distributing loan so that the quality of productive assets is maintained. With maintained loan quality, it is expected that net interest income will increase so that it can ultimately have a positive effect on bank profits. An increase in profit in relation to changes in interest rates is often referred to as the Net Interest Margin, which is the difference between interest income and interest expense (Januarti, 2002).

Distributed Loan based on the purpose of its use is divided into working capital loans, investment loan, and consumer loan (Kasmir, 2013). The greater the loan given by the bank, the greater the potential profit that the bank will get. Based on the period of time, if the loan maturity period is longer, the interest rate given tends to be higher because long-term loan is considered a riskier loan when compared to short-term loan. The amount of NPL from a bank's loan portfolio can decrease if new loans are increased. However, this is not the right solution because this only decreases NPLs temporary. NPLs will continue to grow if new loans that have been given previously also 
experience problems and ultimately reserves formed by banks will be used to cover losses arising from non-performing loans.

Return on Assets (ROA) is an indicator of how profitable a company is relative to its total assets. Profitability is the ability of a company to generate profits by using its assets or capital. The smaller this ratio indicates the lack of bank management capacity in terms of managing assets to increase revenue and or reduce costs (Bank Indonesia, 2011).

\section{Operating Expense to Operating Income}

(BOPO) is a ratio that describes the magnitude of the comparison between operating expenses or costs to a company's operating income in a certain period (Bank Indonesia, 2011). Banks with a high BOPO ratio show that the bank does not operate efficiently because of the high ratio shows the amount of operating expenses that the bank must incur to generate operating income.

Inflation is the rate at which the general level of prices for goods and services is rising and, consequently, the purchasing power of currency is falling in general and continously (Badan Pusat Statistik, 2017). The increase that occurs once even though in a large percentage is not said to be inflation. Inflation is the tendency of rising prices of goods and services in general which occur continuously. High inflation can reduce the real income level obtained by investors from their investments. An increase in the sudden and relatively large inflation rate in a country can have an impact on increasing imports from the country on foreign products so that a lot of foreign currency is needed to pay for the import transaction. This condition will lead to high demand for foreign exchange. Besides, with the increase of inflation, there is a possibility of exports experiencing a decline so that it can reduce foreign exchange reserves in the country.

Bank Indonesia Interest Rate (BI Rate) is a policy interest rate that reflects the monetary policy stance set by Bank Indonesia and announced to the public by the Board of Governors of Bank Indonesia every monthly Board of Governors Meeting and carried out on monetary operations conducted by Bank Indonesia. In general, Bank Indonesia will raise the BI Rate if future inflation is expected to exceed the target set, and on the contrary Bank Indonesia will reduce the BI Rate if future inflation is expected to be below the target set (Bank Indonesia, 2017).

\section{PREVIOUS RESEARCH}

Khan and Ahmad's research (2017) found that ROA has a significant negative effect on NPL. This is due to the political influence at that time and the giving of wrong decisions by 
management in the bank's operations. This result is contrary to Alexandri and Santoso (2015) where ROA has a significant positive effect on NPL. An increase in NPLs can occur along with an increase in ROA in which an increase in bank profits derived from bank loan interest but accompanied by a weak quality of bank management in loan management can have an impact on the increasing number of non-performing loans.

Research by Radivojevic and Jovovic (2017) concluded that NIM had a significant positive effect on NPLs because the creditworthiness of debtors deteriorated over the period observed and some of them might be borrowers who borrowed at higher loan rates, which contributed to the increase in NIMs. The same results were also obtained by Barus and Erick (2016) where the increase in NPLs was due to increased income when banks disbursed loans. With the amount of loans disbursed, the possibility of non-performing loans will also increase so that it will affect the NPL. This research is contrary to Mensah (2015) who found that NIM had a significant negative effect on NPL. The bank received sufficient recovery from its debtor as the bank increased the bank's NIM ratio so that the bank booked a small number of non-performing loans.

According to Barus and Erick (2016), NPL can be influenced by BOPO where the effect is significant positive. The lower BOPO means that banks have higher income so that with increasing income, banks have more resources to handle their loan portfolios and ultimately non-performing loans will also decrease. This is contrary to the research conducted by Vatansever and Hepsen (2013) which states that BOPO has a significant negative effect. This can happen because if the operational costs are higher than operating income, then the operating costs are not efficient, so that it is making the bank in a problematic condition. However, the high operational costs are used to improve the quality of resources owned by banks in granting credit decisions so that the impact on the lowering in non-performing loans.

NPLs are also influenced by CAR. According to Barus and Erick (2016), CAR has a negative effect not significant on NPLs. The research explained that the decline in NPL was caused by the increasing ability of the bank to bear the risk of each loan. The increase in the bank's capabilities was triggered by an increase in the bank's own capital and other sources from outside the bank, such as increased public funds, loans, and others. This research is contrary to Alexandri and Santoso (2015) which states that CAR has a significant positive effect on NPL. This positive relationship can occur because bank capital reserves owned by 
banks are allocated to cover credit risk that occurs so that high capital reserves are followed by high NPLs.

Research by Rajha (2016) found that an increase in inflation resulted in a decrease in NPL caused by high inflation that could increase the ability to pay its obligations by lowering the real value of the remaining outstanding loan. However, Diyanti and Widyarti (2012) in their research gave unequal results, inflation had a positive and significant effect on NPL. Inflation will affect micro and macro economic activities that result in a decline in people's purchasing capability and impact on sales decline. A decrease in sales can reduce operating income. The decline in income will affect the company's ability to pay its loan installments so that this condition will make an increase in NPL.

Loan growth provided by banks can also affect NPLs such as research conducted by Zeleke (2017) with the results of negative and significant influence. Loan growth accompanied by close relationships between creditors and debtors can make banks better in lending and reducing credit risk. This study is contrary to Ahmad and Bashir (2013) who found positive and significant results. This can occur when inadvertent credit disbursement results in the wrong bank giving decisions to debtors who should not have sufficient repayment ability.

Research by Kumala and Suryantini (2015) used interest rate variables as one of the factors that influence NPL. The research was using the BI rate released by Bank Indonesia where it is found that interest rates have a significant negative effect on NPL. This is in line with the research by Romadhoni (2016) which resulted in a significant negative influence in which the increase in interest rates was able to suppress the desire of customers to borrow funds from banks because only capable customers were able to intend to borrow when interest rates were high and underprivileged customers will choose to borrow other than the bank. This research is contrary to Messai and Jouni (2013) and Abid et al (2014) which resulted in a significant positive relationship with NPL. The policy of increasing interest rates has an impact on the debtor's low ability to pay because the higher interest rates on loans can disrupt the debtor's cash flow so that the NPL will increase.

\section{HYPOTHESIS}

The lower bank's profit will have an impact on low reserves or provisions set aside by banks to anticipate potential losses due to nonperforming loans. Current year profit can be used as an increase in capital or an increase in banking business performance so that if the 
profit obtained a little will have an impact on increasing non-performing loans. Research conducted by Zeleke (2017) in Ethiopia found that ROA has a negative effect on NPL. Another study conducted by Rahman et al (2017) in Bangladesh also resulted the same conclusions.

\section{H1: ROA has a negative effect on NPL (See} Ref Figure- 2)

Banks that are inefficient in their activities will result in the inability of banks to compete with fellow banking industries. Efficiency in banks, especially cost efficiency, will result in an optimal level of profit, additional funds to be channeled, more competitive costs, improved services to bank customers, and wellmaintained banking security and health. With good efficiency, the BOPO ratio gets smaller so the problematic loans will also be smaller. The research conducted by Anjom and Karim (2016) in Bangladesh in banks listed on the Dhaka Stock Exchange found that BOPO had a positive effect on NPLs which was in line with research conducted by Barus and Erick (2016) in Indonesia.

\section{H2: BOPO has a positive effect on NPL (See}

\section{Ref Figure- 2)}

The higher the credit risk level the higher the interest rate the bank might require. Since the banks need to have enough reserves to cover additional credit risk to those high-risk debtors.
High NIMs can be obtained from high loan interest rates, while the high interest rates given may impact on the low affordability of debtors. Research conducted by Rahman et al (2017) in Bangladesh found that there was a positive influence between NIM and NPL. This positive relationship is due to loan issues that encourage banks to raise their interest rates to get interest margin to offset the possibility of default.

\section{H3: NIM has a positive effect on NPLs (See}

\section{Ref Figure- 2)}

In general, banks with high capital will be able to deal with risky bank assets so that they can reduce the level of NPLs because capital can function as a buffer to absorb losses arising from various risks. This research is in line with Jameel (2014) in Pakistan with the CAR results negatively affecting NPL.

H4: CAR has a negative effect on NPL (See

\section{Ref Figure- 2)}

NPL ratio is the ratio between total nonperforming loans to total loan so that if the total loan growth increases more than the total nonperforming loan growth then the NPL will decrease. This can happen if the bank is applying the right and prudent loan decision making so the problematic loan may be reduced to keep it low. The results of this study are in line with the study conducted by Zeleke (2017) in Ethiopia, Mensah (2015) in Ghana, Kemraj and Pasha (2009) in Guyana, Ekanayake and 
Azeez (2015) in Srilanka, Sari et al (2017) Rifat (2016) in Bangladesh, and Romadhoni (2016) in Indonesia with the result that loan growth has a negative effect on NPLs.

H5: Loan growth has a negative effect on NPLs (See Ref Figure- 2)

Inflation generally have an adverse impact on the economy. Communities can be panic in dealing with continuously increased price and the economy is not normal because on the one hand there are people with excess of money who will buy goods, while those who lack money cannot buy goods. This condition can encourage people to withdraw savings so that the bank will become a rush, as a result the bank lacks funds and has an impact on bank closure. According to Alexandri and Santoso (2015), inflation can have an impact on economic instability which leads to increased credit risk. Research conducted by Radivojevic and Jovovic (2017) found that inflation has a positive effect on NPL.

H6: Inflation has a positive effect on NPL (See Ref Figure- 2)

The decline in the BI Rate will be impact on the reduction in guarantee interest rates, followed by a decrease in interest rates on third party funds such as current account, saving account, time deposits and a decrease in lending rates so that the risk of NPL will be better. Research conducted by Abid et al (2014) and Messai and
Jouini (2013) found that an increase in rates that occur at any time can add to the burden of repayment by debtors which results in an increase in the number of non-performing loans.

\section{H7: Interest Rate (BI Rate) has a positive effect on NPL}

\section{RESEARCH METHODS}

This type of research is causality research, namely research with the characteristics of the problem in the form of causation between two or more variables. The dependent variable is NPL, while the independent variables are CAR, NIM, loan growth, BOPO, ROA, inflation, and interest rates. (Ref Table $\mathbf{- 1}$ )

The data were using secondary data that were cross sections and time series. Secondary data for the variables CAR, NIM, BOPO, ROA, Loan Growth, and NPL were obtained from audited financial statement each bank for the 2013-2017 period that released by IDX. Inflation data and interest rates (BI Rate) were obtained from Bank Indonesia.

The research population were BUKU II conventional commercial banks in Indonesia. In 2017 there were 53 banks. Of these, 17 shares were listed on the IDX. The sampling technique was performed by using purposive sampling method with conventional banking criteria listed on the IDX since 2013 and 
financial reports were available during the study period. Based on these criteria, 15 bank samples were obtained (Ref Table 2).

\section{METHOD OF DATA ANALYSIS}

Descriptive Analysis. The analysis is to describe systematically and factually about the facts and the relationship between the variables under study where the existing data is collected, classified, analyzed, and interpreted objectively so that it can provide information and an overview of the topics discussed

Inferential Analysis. This Analysis is using multiple linear regression approaches. The independent variables are CAR (X1), NIM (X2), Loan growth (X3), BOPO (X4), ROA (X5), Inflation (X6), Interest Rate (X7) and the dependent variable is NPL (Y).

Regression equation is:

$$
\begin{aligned}
Y_{i t}=a+b_{1} X_{1_{i t}} & +b_{2} X_{2_{i t}}+b_{3} X_{3 i t}+b_{4} X_{4_{i t}} \\
+ & b_{5} X_{5_{i t}}+b_{6} X_{6 i t}+b_{7} X_{7_{i t}}+e
\end{aligned}
$$

Note:

$$
\begin{array}{ll}
\mathrm{b} 1-\mathrm{b} 7 & =\text { Coefficient Regression } \\
\mathrm{a} & =\text { Constanta } \\
\mathrm{e} & =\text { Standard Error }
\end{array}
$$

This study uses panel data because it is a combination of cross section and time series. Panel data regression model can be in the form of (1) Pooled Least Square (PLS), (2) Fixed
Effect Approach, and (3) Random Effect Approach.

The selection of the best panel models is done through (1) Chow Test. Test to determine whether the model used is PLS or fixed effect, (2) Hausman test. Test to determine whether the model is the best fixed effect or random effect, and (3) the Lagrange Multiplier test. Test to find out whether the best model is PLS or random effect.

After the best panel model is found, the analysis of the regression model is performed through (1) F Test (Simultaneous Test) to determine whether the regression model is appropriate to explain the phenomenon of the problem or not and (2) the Coefficient of Determination (Test $R^{2}$ ) shows the ability of independent variables in explaining the variability of dependent variable. Then $t$ test (Partial Influence Test) is carried out. This test is conducted to determine the effect of each independent variable on the dependent variable.

\section{RESULT AND DISCUSSION}

The average value of NPL was $2.79 \%$. The lowest value was $0 \%$ held by Bank Nationalnobu (NOBU) in 2013 to 2016, while the highest value was $15.82 \%$ owned by the Bank of India Indonesia (BSWD) in 2016. The bank's NPL was high and if we traced by the bank's 2016 financial report, then we found the 
NPL net reaches $4.69 \%$ where this figure was close to the OJK's maximum rule of $5 \%$. When we viewed from the gross NPL value of $15.82 \%$ with NPL net of $4.69 \%$ in Bank of India Indonesia, it could be said that the bank formed a high CKPN (Allowance for Impairment Losses) where high CKPN can affect the ability to expand business the bank in the next year period. (Ref Table - 3)

The highest CAR ratio held by National Bank (NOBU) in 2013 was $87.49 \%$. The high CAR ratio of NOBU banks was due to an increase in capital made through the IPO (Initial Public Offering) in 2013. The lowest CAR ratio was owned by Bank JTrust Indonesia (BCIC) in 2014 of $13.48 \%$. This was due to the high number of non-performing loans in the year that affected the increase in risk-weighted assets, particularly credit risk, as a legacy of the old management which subsequently transferred 99.996\% of shares from LPS to J-Trust Co. Ltd. The average value of NIM was $4.41 \%$. The highest NIM ratio held by Bank Mestika Dharma (BBMD) in 2013 was 8.26\%. The high NIM ratio of BBMD is due to the growth of interest income of $10.67 \%$ which is higher than the growth of interest cost of $7.57 \%$ with the growth of productive assets of $6.22 \%$. The lowest NIM ratio owned by Bank JTrustIndonesia (BCIC) in 2014 was $0.24 \%$. Some of the causes of low NIMs of BCIC banks are the impact of the old management quality, namely the high number of non-performing loans, which was resulting in low interest income and a transfer of ownership from LPS to J-Trust Co. Ltd that could affected credit policies.

The average value of loan growth was $20.34 \%$. The highest loan growth owned by National Bank (NOBU) in 2013 was 199.88\%. The high NOBU loan growth was due to business expansion efforts that focused on Small and Medium Enterprises and the development of loan products supported by the opening of offices in 2013 which were spread in 30 cities (19 provinces). Meanwhile, the lowest loan growth was owned by Bank of India Indonesia (BSWD) in 2016 of $-30.41 \%$. This is because in 2016 the BSWD bank focused more on adding reserve funds for non-performing loans and recovery on non-performing loans.

The average value of BOPO was $94.63 \%$. The highest BOPO ratio held by Bank of India Indonesia (BSWD) in 2016 was 235.2\%. The high ratio of BSWD BOPO banks was due to an increase in operating expenses greater than an increase in operating income, where the increase in operating expenses was due to an increase in the formation of CKPN. While the lowest BOPO ratio owned by Bank Mestika Dharma (BBMD) in 2013 was 54.13\%. 
The highest ROA ratio held by Bank Mestika Dharma (BBMD) in 2013 was $5.42 \%$ while the lowest ROA ratio was owned by Bank of India Indonesia (BSWD) in 2016 of $-11.15 \%$. This was due to the high number of non-performing loans which requires BSWD banks to form CKPN (Allowance for Impairment Losses) in anticipation of the potential for deteriorating existing loan resulting in a loss of banks. The average value of ROA was $0.66 \%$, meaning that on average every one hundred rupiahs of assets can generate a net profit of 0.66 rupiah.

The highest inflation occurred in 2013 was $8.38 \%$ while the lowest inflation occurred in 2016 was $3.02 \%$. The average value of inflation was $5.34 \%$.

The highest interest rate occurred in 2014 at $7.75 \%$ while the lowest interest rate occurred in 2017 at $4.25 \%$. The average interest rate is $6.35 \%$. According to Bank Indonesia, changes in the BI rate can change along with changes in inflation.

The test results shown that the Random Effect was the best panel model (Ref Table 4).

\section{Determination Coefficient $\left(\mathbf{R}^{2}\right.$ Test). Based} on the Random Effect model presented in (Ref Table 5), it was known that the Adjusted Rsquared coefficient was 0.588 . This means that $58.8 \%$ of the variability of NPL can be explained by the variables of ROA, BOPO,
NIM, CAR, loan growth, inflation, and interest rates (BI Rate). The remaining $41.2 \%$ is explained by other variables which are not examined in this study.

Table 5 presents the calculated $\mathrm{F}$ value of 16.094 with a significance of 0.000 . This means the regression model is formed accordingly.

Based on (Ref Table 5), the resulting regression equation is as follows:

$N P L=3,061-0,933 R O A-0,008 B O P O+$ $0,18 N I M+0,02 C A R-0,0184$ LoanGrowth + 0,028Inflation + 0,019InterestRate

\section{FINDING AND ANALYSIS}

\section{Influence of ROA on NPL}

Partial testing results show that ROA has a negative and significant effect on NPL. If ROA rises by $1 \%$, the NPL will decrease by $0.93 \%$. Increased ROA shows the greater the level of profit achieved by the bank and the better the bank is in terms of utilizing its assets. One asset that is generally owned by banks is technology that supports accuracy and speed in deciding credit approval, for example is a credit scoring application that is equipped with a risk assessment. Other technologies that support such as debtor monitoring and reminder applications are delinquent so the bank has an early warning system to prevent nonperforming loans. The better the use of assets, 
the bank can reduce the risk of non-performing loans because banks are more careful in distributing loan.

For banks that have a variety of loan products and those with large amounts of loan generally will not depend on that system application so that it is still necessary to increase and develop the ability of all resources owned by the bank to manage loans. Credit, as the bank's biggest asset, must be managed properly. Banks with a high level of profit can use training costs, such as training in credit analysts, marketing training, and others, so that banks have competent resources to provide decisions and monitor credit so that banks can keep nonperforming loans low.

The result of this study is in line with the research conducted by Khan and Ahmad (2017) in Pakistan for the period 2006-2016, Anjom and Karim (2016) in Bangladesh for the period 2010-2014, Zeleke (2017) in Ethiopia for the period 2002-2015, Rahman et al ( 2017) in Bangladesh for the period 2010-2015, Wardoyo and Rusdiyanti (2009) at BPRs in Indonesia in 2007, Messai and Jouini (2013) in Italy, Greece and Spain for the 2004-2008 period, Radivojevic and Jovovic (2017) in 25 countries in the period 2000-2011, and Ekanayake and Azeez (2015) in Sri Lanka in the period 19992012. The results of this study contradict the research conducted by Ahmad and Bashir
(2013) which found that ROA has a positive and significant effect on NPL. The imprudent bank's management strategy to increase profit targets can lead to error in credit disbursement that should be given to decent debtors. If bank disbursed loan to low quality debtors in repayment capability, then it will result in an increase of NPL.

\section{Influence of BOPO on NPL}

The partial test result shows that BOPO has a negative effect but not significant to NPL. This explains that the efforts of operational efficiency carried out by banks have not been able to significantly influence the decline in NPLs. The result of this study is in line with the research conducted by Ahmad and Bashir (2013) in Pakistan for the 2006-2011 period and Vatansever and Hepsen (2013) in Turkey for the 2007-2013 period. This research is contrary to Santosa et al (2014) who found that BOPO has a positive and significant effect on NPL.

\section{Influence of NIM on NPL}

The partial test result shows that NIM has a positive but not significant effect on NPL. This explains that efforts to increase net interest income by banks have not been able to significantly influence the increase in NPLs. This research is in line with the research conducted by Rahman et al (2017) in Bangladesh for the period 2010-2015 and Sari 
et al (2017) in Indonesia for the 2012-2015 period. The result of this research is contrary to Mensah (2015) who found that NIM had a negative and insignificant effect on NPL.

\section{Influence of CAR on NPL}

Partial testing result shows that CAR has a positive and insignificant effect on NPL. This explains that bank capital cannot have a significant effect on NPLs where a positive relationship can occur if the provision of high risk loans that are not offset by an increase in the amount of bank capital will have an impact on the increased NPL. The result of this study is in line with the research conducted by Vatansever and Hepsen (2013) in Turkey in the period 2007-2013, Alexandri and Santoso (2015) in the BPD in Indonesia for the period 2009-2013, and Gambo et al (2017) in Nigeria for the period 2010-2014 that CAR has a positive and not significant effect on NPL. The result of this study is contrary to Kumala and Suryantini (2015) and Jameel (2014) who find that CAR has a negative and significant effect on NPL. Banks that have high capital will be better able to manage bank assets at risk because capital can function as a buffer to absorb losses arising from various risks so that it can reduce NPL.

\section{Influence of Loan Growth on NPL}

The partial test result shows that loan growth has a negative and significant effect on NPL. Increased loan growth can reduce the level of non-performing loans because each new loan distribution is expected to be a loan that is smoothly returned so that banks can reduce the NPL ratio by increasing the distribution of new loans. In general, each disbursed loan has the potential to become a non-performing loan so that the new loan distribution needs to be supported by a good credit analysis so the NPL ratio is kept low, for example by recruiting reliable credit analysts, credit policy updates, use of credit acceptance technology, and others. The results of this study are in line with the research conducted by Zeleke (2017) in Ethiopia for the period 2002-2015, Mensah (2015) in Ghana, Kemraj and Pasha (2009) in Guyana in the period 1994-2004, Ekanayake and Azeez (2015) in Sri Lanka in 1999-2012, Sari et al (2017) in the 2012-2015 period and Romadhoni (2016) in the 2011-2014 period in Indonesia, and Rifat (2016) in Bangladesh for the period 2003-2014. The results of this study are different from Ahmad and Bashir (2013) who find credit growth has a positive and significant effect on NPL. The inadvertent growth in lending can cause banks to provide credit to debtors who should not meet the 
expected credit quality so that the bank's NPLs increased.

\section{Influence of Inflation on NPL}

The partial test result shows that inflation has a positive and insignificant effect on NPL. This explains that the increased inflation condition has no significant effect on increasing NPL. The result of this study is in line with the research conducted by Alexandri and Santoso (2015) on BPD in Indonesia for the period 2009-2013, Gambo et al (2017) in Nigeria for the period 2010-2014, and Rifat (2016) in Bangladesh for the period 2003-2014. The result of this study contradict the results of research by Barus and Erick (2016) and Rajha (2016) who found inflation had a negative and significant effect on NPLs and Shingjergji and Shingjergji (2013) which found inflation had a negative but not significant effect on NPL.

\section{Influence of Interest Rate (BI Rate) on NPL}

The partial test result shows that the interest rate (BI Rate) has a positive and insignificant effect on the NPL. This explains that the reduction in interest rates (BI Rate) has no significant effect on the decline in NPLs. The result of this study is in line with the research conducted by Fajar and Umanto (2017) in Indonesia for the period of 2005-2014. The results of this study is contrary to Romadhoni (2016) who found interest rates (BI Rate) to have a negative and significant effect on NPL. Romadhoni found that the increase in interest rates (BI Rate) could have an impact on the increase in bank lending rates which resulted in the ability of the debtor to restore loans to decline so that NPLs increased.

\section{SUMMARY \& SUGGESTION}

Based on the results of the analysis and discussion that has been explained, it can be concluded that the BUKU II banks listed on the IDX, ROA and credit growth have a negative and significant effect on NPL, BOPO has a negative effect but not significant on NPL. NIM and CAR have positive effect but not significant on NPL. Macroeconomic factors, namely inflation and interest rates (BI Rate), have a positive but not significant effect on NPL.

Investors can choose BUKU II banks listed on the IDX as a place to invest their funds. Bank selection should be based on ROA because ROA has the greatest influence on the decline in NPLs. The lower the NPL of a bank, the smaller the risk.

In addition, investors can also pay attention to loan growth as a consideration and support in the selection of investments in banks listed on the IDX. The greater the loan growth of BUKU II banks, the smaller the NPL will be. 
In order for banks to increase ROA, management needs to increase profitgenerating capabilities, for example by increasing fee-based income such as bancassurance or online transactions, and so on. The coefficient of determination in this study is relatively low, for that in subsequent studies should be added other factors that affect NPL such as the RWA variable (Risk Weighted Assets) by specifically discussing assets based on credit risk because it is more related to NPL. In addition, to ascertain the factors influencing the NPL related to the bank's interest margin, further research can add interest margin variables based on the type of credit usage, namely investment credit, working capital credit, and consumption credit. This needs to be done considering credit risk on consumption credit is higher than non-consumption credit, so banks usually give higher interest rates for consumption credit. Other external factors that can be used as research variables such as currency exchange rates because bank financing often also uses foreign exchange rates.

\section{REFERENCE}

Abid, Lobna, Med Nejib Ouertani, and Sonia Zouari-Ghorbel. 2014. "Macroeconomic and Bank-Specific Determinants of Houshold's Non-Performing Loans in
Tunisia: A Dynamic Panel Data”. Procedia Economics and Finance, Elsevier B. V. 13, pp 58-68.

Ahmad, Fawad and Taqadus Bashir. 2013. "Explanatory Power of Bank Specific Variables as Determinants of NonPerforming Loans: Evidence from Pakistan Banking Sector". World Applied Sciences Journal, IDOSI Publications. 2 (9) pp 1220-1231.

Alexandri, Moh Benny and Teguh Iman Santoso. 2015. "Non Performing Loan: Impact of Internal and External Factor (Evidence in Indonesia)". International Journal of Humanities and Social Science

Invention. Vol 4, Issue 1, pp 87-91.

Ali, Masyhud. 2004. Asset Liability Management: Menyiasati Risiko Pasar dan Risiko Operasional. PT Elex Media Komputindo. Gramedia. Jakarta.

Anjom, Washeka, and Asif Mahbub Karim. 2016. "Relationship between NonPerforming Loan and Macroeconomic Factors with Bank Specific Factors: A Case Study on Loan Portfolios - SAARC Countries Perspective". ELK Asia Pacific Journal of Finance and Risk Management. Vol 7 Issue 2.

Badan Pusat Statistik. 2017. Istilah Inflasi. https://www.bps.go.id/istilah.html (Accessed at August 03, 2017) 
Bank Indonesia. 2011. Peraturan Perbankan. https://www.bi.go.id/id/peraturan/perbank an/Pages/

SE\%20No.13_24_DPNP_2011.aspx

(Accessed at April 12, 2017)

sebagai Suku Bunga Acuan.

https://www.bi.go.id/id/moneter/bi-

rate/penjelasan/Contents/Default.aspx

(Accessed at August 03, 2017)

Barus, Andreani Caroline and Erick. 2016. "Analisis Faktor-Faktor yang Mempengaruhi Non Performing Loan pada Bank Umum di Indonesia". Jurnal Wira Ekonomi Mikroskil. Vol 6, No 2, pp 113122.

Diyanti, Anin and Endang Tri Widyarti. 2012 "Analisis Pengaruh Faktor Internal dan Eksternal Terhadap Terjadinya NonPerforming Loan (Studi Kasus pada Bank Umum Konvensional yang Menyediakan Layanan Kredit Pemilikan Rumah Periode 2008-2011)". Diponegoro Journal of Management. Vol 1, No 2, pp 290-299.

Ekanayake, Nishani and A. A. Azeez. 2015. "Determinants of Non-Performing Loans in Licensed Commercial Banks: Evidence from Sri Lanka”. AESS Publications. Vol 5(6), pp 868-882.

Fajar, Hanifan and Umanto. 2017. "The Impact of Macroeconomic and Bank-Specific
Factors Toward Non-Performing Loan: Evidence from Indonesian Public Banks". Banks and Bank Systems Journal, Business Perspective. Vol 12, Issue 1, pp 67-74. Gambo, El-Maude Jibreel, Ahmad AbdulRahman, and Muhammad Ibrahim. 2017. "Determinants of Non-Performing Loans in Nigeria's Deposit Money Banks". Archives of Business Research, Society for Science and Education, United Kingdom. Vol 5, No 1, pp 74-88.

Jameel, Kiran. 2014. "Crucial Factors of Nonperforming Loans Evidence from Pakistani Banking Sector”. International Journal of Scientific \& Engineering Research. Vol 5, Issue 7, pp 704-710.

Januarti, Indira. 2002. "Variabel Proksi CAMEL dan Karakteristik Bank Lainnya untuk Memprediksi Kebangkrutan Bank di Indonesia”. Jurnal Bisnis Strategi. Vol 10, pp 1-10.

Kasmir. 2013. Bank dan Lembaga Keuangan Lainnya. PT Raja Grafindo Persada. Jakarta.

Khan, Ihtesham and Adnan Ahmad. 2017. "Assessing Banks Internal Factors as Determinants of Non-Performing Loans: Evidence from Pakistani Commercial Banks". Journal of Managerial Sciences. Vol IX No 1, pp 109-125. 
Khemraj, Tarron and Sukrishnalall Pasha. 2009. "The Determinants of NonPerforming Loans: An Econometric Case Study of Guyana". Munich Personal RePEc Archive Paper. Vol 23, No 53128, pp 1-25.

Kumala, Putu Ayu Sintya and Ni Putu Santi Suryantini. 2015. "Pengaruh Capital Adequacy Ratio, Bank Size, dan BI Rate Terhadap Risiko Kredit (NPL) pada Perusahaan Perbankan". E-Jurnal Manajemen Unud. Vol 4, No 8, pp 22282242.

Mensah, Franklin Amuakwa. 2015. "Determinants of Non-Performing Loans in Ghana Banking Industry". Int. J. Computational Economics and Econometrics. Vol 5, No 1, pp 35-54.

Messai, Ahlem Selma and Fathi Jouini. 2013. "Micro and Macro Determinants of NonPerforming Loans". International Journal of Economics and Financial Issues. Vol 3, No 4, pp 852-860.

Otoritas Jasa Keuangan. 2017. Statistik Perbankan Indonesia. https://www.ojk.go.id/id/kanal/perbankan/ data-dan-statistik/statistik-perbankanindonesia/Default.aspx (Accessed at March 12, 2018)

Radivojevic, Nikola and Jelena Jovovic. 2017. "Examining of Determinants of Non-
Performing Loans". Prague Economic Papers. Vol 26, No 3, pp 300-316.

Rahman, Md Ataur, Md Asaduzzaman, and Md Shakhaowat Hossin. 2017. "Impact of Financial Ratios on Non-Performing Loans of Publicly Traded Commercial Banks in Bangladesh". International Journal of Financial Research. Vol 8, No 1, pp 181188.

Rajha, Khaled Subhi. 2016. "Determinants of Non-Performing Loans: Evidence from the Jordanian Banking Sector". Journal of Finance and Bank Management. Vol 4, No 1, pp 125-136.

Rifat, Apel Mahmood. 2016. "An Analytical Study of Determinants of Non-Performing Loans: Evidence from Non-Bank Financial Institutions (NBFIs) of Bangladesh". Journal of Business and Technology (Dhaka). Vol XI, No 01 \& 02, pp 55-67.

Romadhoni, Revita. 2016. "Pengaruh Loan to Deposit Ratio, Suku Bunga BI Rate, dan Pertumbuhan Kredit Terhadap Kredit Bermasalah Sub Sektor Perbankan pada Indeks LQ45 di Bursa Efek Indonesia (BEI)". Thesis. Economics and Business Faculty. Universitas Lampung. Bandar Lampung.

Santosa, Septiono Budi, Sudarto, and Bambang Sunarko. 2014. "Analisis Pengaruh LDR, BOPO, SIZE, LAR, dan NIM terhadap 
NPL pada BPR Konvensional di Wilayah Jawa Tengah (Periode 2010-2012)". Journal \& Proceeding Fakultas Ekonomi dan Bisnis Universitas Jendral Soedirman. Volume 4, No 1, pp 687-699.

Sari, Brilia Wulantika, D.S Priyarsono, and Lukytawati Anggraeni. 2017. "BankSpecific and Macroeconomic Determinants of Non-Performing Loan of Regional Development Banks in Indonesia". International Journal of Science and Research (IJSR). Vol 6, Issue 2, pp 634-637.

Shingjergji, Ali and Iva Shingjergji. 2013. "An Analysis of the Nonperforming Loans in the Albanian Banking System". International Journal of Business and Commerce. Vol 2, No 6, pp 01-11.
Tohir, Noel Chabannel. 2013. Panduan Lengkap Menjadi Account Officer. Edisi 5. PT Elex Media Komputindo. Jakarta.

Vatansever, Metin and Ali Hepsen. 2013. "Determining Impacts on Non-Performing Loan Ratio in Turkey". Journal of Finance and Investment Analysis. Vol 2, No 4, pp 119-129.

Wardoyo, Paulus dan Endang Rusdiyanti. 2009. "Faktor-Faktor yang Mempengaruhi Non Performing Loan Bank Perkreditan Rakyat di Eks Karesidenan Semarang”. $J$. Dinamika Sosbud. Vol 11, No 2, pp 127139.

Zeleke, Belayneh. 2017. "Determinent of Non Performing Loans: The Case of Ethiopian Commercial Banks". Thesis. Department of Accounting and Finance. Addis Ababa University.

\section{LIST OF TABLES}

Table 1. Operationalization of Variables

\begin{tabular}{ll}
\hline \multicolumn{1}{c}{ Variable } & \multicolumn{1}{c}{ Indicator } \\
\hline Non Performing Loan $(\mathrm{Y})$ & $\begin{array}{l}\mathrm{NPL}=(\text { Substandard Loan }+ \text { Doubtful Loan }+ \text { Loss Loan }) / \text { Total } \\
\text { Loan }\end{array}$ \\
\hline CAR (X1) & CAR $=$ Capital/Risk Weighted Assets for Credit Risk, Operational \\
& Risk, and Market Risk \\
\hline NIM (X2) & NIM $=$ Net Investment Income $/$ Average Earning Assets \\
\hline Loan Growth (X3) & Loan Growth $=\left(\right.$ Total Loan $_{\mathrm{t}}-$ Total Loan $\left._{\mathrm{t}-1}\right) /$ Total Loan \\
\end{tabular}




\begin{tabular}{ll}
\hline BOPO (X4) & BOPO = Total Operating Expense / Total Operating Income \\
\hline ROA (X5) & ROA = Profit Before Tax / Average Total Asset \\
\hline Inflasi (X6) & Inflation Rate Published by Bank Indonesia \\
\hline $\begin{array}{l}\text { Interest Rate (BI Rate) } \\
\text { (X7) }\end{array}$ & BI Rate Published by Bank Indonesia \\
\hline
\end{tabular}

Table 2. Research Sample

\begin{tabular}{|c|c|c|c|}
\hline No & Code & Name & $\begin{array}{l}\text { Core Capital per } \\
\text { December 31, } 2017 \\
\text { (in Million Rupiahs) }\end{array}$ \\
\hline 1 & AGRO & Bank Rakyat Indonesia Agroniaga Tbk & $3,071,345$ \\
\hline 2 & BACA & Bank Capital Indonesia Tbk & $1,229,379$ \\
\hline 3 & BBMD & PT Bank Mestika Dharma Tbk. & $2,905,128$ \\
\hline 4 & BBNP & Bank Nusantara Parahyangan Tbk & $1,102,676$ \\
\hline 5 & BCIC & PT Bank JTrust Indonesia Tbk. & $1,511,101$ \\
\hline 6 & BKSW & PT Bank QNB Indonesia Tbk & $3,468,141$ \\
\hline 7 & BMAS & PT Bank Maspion Indonesia Tbk. & $1,105,102$ \\
\hline 8 & BNBA & Bank Bumi Arta Tbk & $1,329,768$ \\
\hline 9 & BSIM & Bank Sinarmas Tbk & $4,343,974$ \\
\hline 10 & BSWD & Bank of India Indonesia Tbk & $1,024,130$ \\
\hline 11 & BVIC & Bank Victoria International Tbk & $2,705,546$ \\
\hline 12 & INPC & Bank Artha Graha Internasional Tbk & $3,742,813$ \\
\hline 13 & MCOR & $\begin{array}{l}\text { PT Bank China Construction Bank } \\
\text { Indonesia Tbk }\end{array}$ & $2,017,520$ \\
\hline 14 & NOBU & PT Bank Nationalnobu Tbk. & $1,323,355$ \\
\hline 15 & SDRA & $\begin{array}{l}\text { PT Bank Woori Saudara Indonesia } 1906 \\
\text { Tbk }\end{array}$ & $3,973,459$ \\
\hline
\end{tabular}


Table 3. Descriptive Statistics of Research Variables

\begin{tabular}{l|rrr}
\hline \multicolumn{1}{c}{ Variabel } & \multicolumn{1}{c}{ Mean } & \multicolumn{1}{c}{ Maximum } & \multicolumn{1}{c}{ Minimum } \\
\hline NPL & 2.7900 & 15.8200 & 0.0000 \\
CAR & 21.7967 & 87.4900 & 13.4800 \\
NIM & 4.4115 & 8.3600 & 0.2400 \\
Loan Growth & 20.2344 & 199.8800 & -30.4100 \\
BOPO & 94.6303 & 235.2000 & 54.1300 \\
ROA & 0.6660 & 5.4200 & -11.1500 \\
Inflation & 5.3440 & 8.3800 & 3.0200 \\
Interest Rate & 6.3500 & 7.7500 & 4.2500 \\
\hline
\end{tabular}

Tabel 4. Conclusion of Model Selection Result

\begin{tabular}{|c|c|c|c|}
\hline Model Testing & $\begin{array}{c}\text { Test Stat Value } C h i- \\
\text { Square }\end{array}$ & Sign. & Result \\
\hline Chow & 41.675104 & 0.0001 & Fixed Effect \\
\hline Hausman & 0.000000 & 1.0000 & Random Effect \\
\hline Lagrange & 6.552710 & 0.0105 & Random Effect \\
\hline Multiplier & & & \\
\hline
\end{tabular}

ROA, BOPO, NIM, CAR, Loan Growth, Inflation, and Interest Rate (BI Rate) on NPLs on BUKU II Banking in 2013 - 2017 with Random Effect Model

\begin{tabular}{l|ccc}
\multicolumn{1}{c}{ Variable } & Coefficient & t-Statistic & Sign. \\
\hline C & 3,060636 & 0,963377 & 0,3388 \\
ROA & $-0,933389$ & $-2,789978$ & $0,0069^{* * *}$ \\
BOPO & $-0,008294$ & $-0,255366$ & 0,7992 \\
NIM & 0,180454 & 1,005509 & 0,3183 \\
CAR & 0,02001 & 0,739857 & 0,462 \\
LoanGrowth & $-0,018405$ & $-2,136534$ & $0,0363^{* *}$ \\
Inflasi & 0,028019 & 0,278227 & 0,7817
\end{tabular}


ELK ASIA PACIFIC JOURNAL OF FINANCE AND RISK MANAGEMENT

ISSN 2349-2325 (Online); DOI: 10.16962/EAPJFRM/issn. 2349-2325/2015; Volume 9 Issue 4 (2018)

\begin{tabular}{l|ccc} 
InterestRate & 0,019891 & 0,12083 & 0,9042 \\
\hline R-squared & 0,627074 & \\
Adjusted R-squared & 0,588112 & \\
F-statistic & 16,09433 & \\
Prob(F-statistic) & 0,00000 & \\
\hline
\end{tabular}

Note: $* * \quad$ Significant at $\alpha=5 \%$;

*** Significant at $\alpha=1 \%$

\section{LIST OF FIGURES}

Figure 1. Conventional Commercial Banks Condition in Indonesia Accumulatively in 2013 $-2017$

Source: Otoritas Jasa Keuangan (2017)

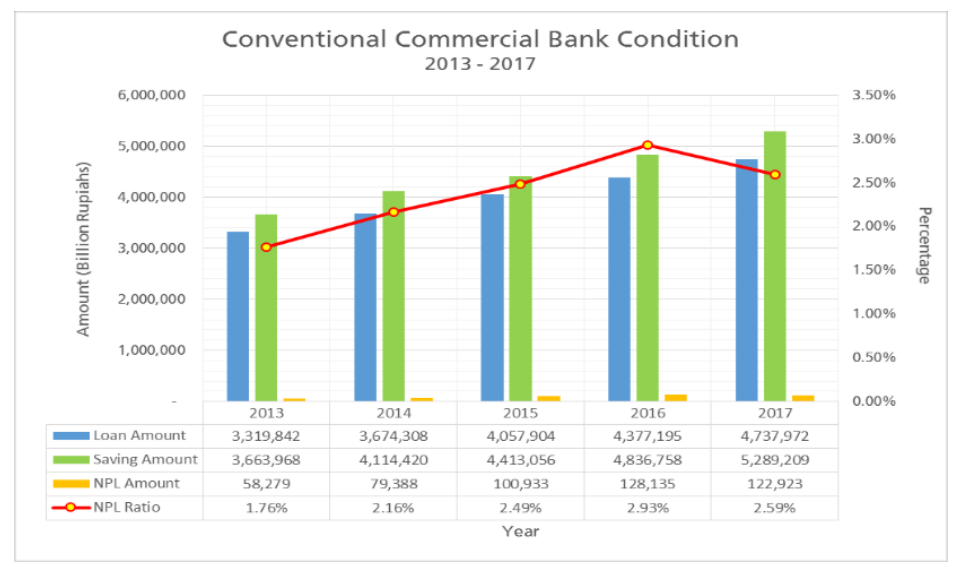

Figure 2. Research Framework

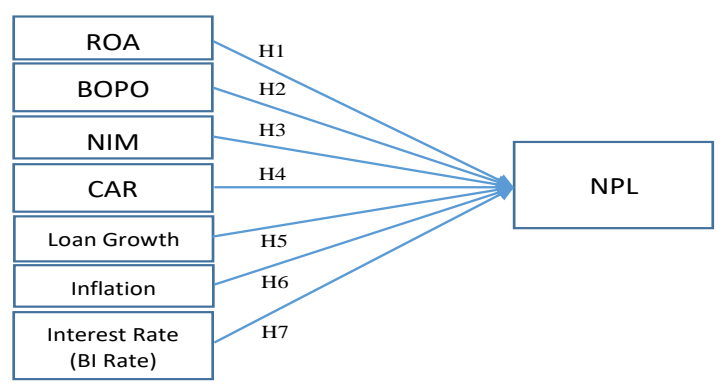

